\title{
Comparative study of water-processing in two ciliary filter-feeding polychaetes (Ditrupa arietina and Euchone papillosa) from two different habitats
}

\author{
H. U. Riisgård ${ }^{1, *}$, A. Grémare ${ }^{2}$, J. M. Amouroux ${ }^{2}$, F. Charles ${ }^{2}$, G. Vétion ${ }^{2}$, \\ R. Rosenberg ${ }^{3}$, C. Nielsen ${ }^{4}$ \\ ${ }^{1}$ Marine Biological Research Centre, Institute of Biology, University of Southern Denmark, Hindsholmvej 11, \\ 5300 Kerteminde, Denmark \\ ${ }^{2}$ Observatoire Océanologique de Banyuls, Université Pierre et Marie Curie, CNRS UMR 7621, BP 44, \\ 66651, Banyuls-sur-Mer Cedex, France
}

${ }^{3}$ Department of Marine Ecology, Göteborg University, Kristineberg Marine Research Station, 45034 Fiskebäckskil, Sweden

${ }^{4}$ Zoological Museum, University of Copenhagen, Universitetsparken 15, 2100 Copenhagen, Denmark

\begin{abstract}
A comparative study of feeding rates and structures was made with the 2 ciliary filterfeeding polychaetes Ditrupa arietina and Euchone papillosa from the Mediterranean Sea (Gulf of Lions, France) and the Gullmarsfjord (Sweden), respectively. The feeding rate (clearance) was measured as the volume of water cleared of $6 \mu \mathrm{m}$ diameter flagellate cells (Rhodomonas sp.) per unit time. Most experiments were conducted at algal concentrations equivalent to about 0.4 to $3.8 \mu \mathrm{g}$ chlorophyll a $\mathrm{l}^{-1}$. The clearance rates of 'standard' $1.5 \mathrm{mg}$ dry wt E. papillosa and 'standard' $3.0 \mathrm{mg}$ dry wt $D$. arietina showed that the maximum weight-specific clearance rate was $114.7 \mathrm{ml} \mathrm{h}^{-1} \mathrm{mg}^{-1}$ for $E$. papillosa and about 7 times lower, $15.7 \mathrm{ml} \mathrm{h}^{-1} \mathrm{mg}^{-1}$, for $D$. arietina. A relative large tentacle crown in E. papillosa, resulting in the higher specific clearance rate, may be the evolutionary result of 'minimal scaling' and adaptation to extremely low food concentrations. When the algal concentration was increased from 2000 to 10000 cells ml ${ }^{-1}$ a $50 \%$ decrease in the clearance rate was observed in $D$. arietina, presumably because the gut capacity was exceeded. A more pronounced tendency to become satiated was found for E. papillosa. No tendency to reduce the filter-feeding activity at even very low algal concentrations was noticed in the 2 polychaetes, and the filtering activity of both worms seems to be a basically continuous process. Video-microscope observations of E. papillosa showed that suspended algal cells approaching the pinnules suddenly accelerate and move through an arc of over $180^{\circ}$ to be delivered on the frontal side of the pinnule. The transfer takes place at a maximum distance (radius) of about $25 \mu \mathrm{m}$ from the pinnule. Scanning micrographs show the compound lateral cilia to be 20 to $25 \mu \mathrm{m}$ long in both $D$. arietina and E. papillosa and to consist of 1 row of 4 cilia. The feeding current is generated by these compound cilia, which, during their power stroke, catch up with the particles.
\end{abstract}

KEY WORDS: Suspension-feeding · Filtration rates · Particle-retention mechanism · Adaptation to the environment $\cdot$ Feeding structures

\section{INTRODUCTION}

Ciliary filter-feeding occurs in many polychaetes (Fauchald \& Jumars 1979, Nielsen 1987). Ciliated tentacle crowns functioning as downstream collecting sys-

*E-mail: hur@biology.sdu.dk tems, based on the 'catch-up principle', is characteristic of the families Sabellidae and Serpulidae. Their compound lateral cilia (cirri) generate a feeding current that enters the ciliary region where the same cilia, during their power stroke, catch up with suspended particles and transfer them to a frontal band of separate cilia on the downstream side; the frontal band transports the captured particles towards the mouth 
(Riisgård et al. 2000). Different aspects of filter-feeding in the sabellid polychaete Sabella pavonina have been studied during recent years. Jørgensen et al. (1984) determined the particle-retention efficiency; Riisgård \& Ivarsson (1990) measured clearance rates; Mayer (1994) measured the particle velocity during the capture phase; and recently Mayer (2000) made a numerical simulation of flow fields and particle trajectories. The particle-capture mechanism and the feeding structures of the serpulid tentacle crown of Spirorbis tridentatus has recently been studied by Riisgård et al. (2000). It was found that $S$. tridentatus uses the same basic principle of ciliary 'catch-up' of particles as adopted by the entoproct Loxosoma pectinaricola and the cycliophore Symbion pandora.

The population density of ciliary filter-feeding polychaetes may be high in some marine areas. Over the last 25 yr the serpulid polychaete Ditrupa arietina, which lives in an unattached tusk-shaped, thick and calcareous tube (up to $\sim 3.5 \mathrm{~cm}$ long), has become the dominant macrofaunal species on sandy bottoms in the Gulf of Lions (north-western Mediterranean Sea), with adult densities reaching more than 3000 ind. $\mathrm{m}^{-2}$ (Grémare et al. 1998b), resulting in a significant contribution of this polychaete to benthic secondary production and calcification (Medernach et al. 2000). The abundance is extremely high for the oligotrophic Mediterranean Sea, which typically has a low biomass but a high diversity of benthic macrofauna (Guille 1971). When the worm (body length $\approx 1 \mathrm{~cm}$ ) is undisturbed and actively filter-feeding, the tentacle crown (length of tentacles $\approx 0.3 \mathrm{~cm}$ ) is stretched out of the tube. When the highly sensitive worm becomes disturbed, it withdraws quickly into the tube, which is firmly closed by means of the flattish lens-shaped operculum. To further assess the ecological role of $D$. arietina, knowledge about water-processing and other aspects of the feeding biology is needed (Jordana et al. 2000).

The sabellid Euchone papillosa is found on muddy bottoms at depths between 15 and $100 \mathrm{~m}$ in the Gullmarsfjord on the Swedish west coast. The abundance varies from a few up to 200 ind. $\mathrm{m}^{-2}$. The worm lives in a thin-walled tube (outer diameter $\approx 1 \mathrm{~mm}$ ), built of mucoprotein with silt, which penetrates 3 to $8 \mathrm{~cm}$ into the sediment and stretches 5 to $7 \mathrm{~cm}$ up into the water column. When the worm (body length $\approx 1 \mathrm{~cm}$ ) is undisturbed and actively filter-feeding the flat or somewhat funnel-shaped tentacle crown (length of tentacles $\approx 0.6 \mathrm{~cm}$ ) is stretched out of the tube. E. papillosa is not amongst the dominant benthic species in the fjord, which is dominated by deposit-feeding animals at $75 \mathrm{~m}$ depth (Nilsson \& Rosenberg 2000).

The adaptation of filter-feeders to ambient concentrations of suspended food particles is a subject of wide interest, and also current controversy. It is well known that food availability may affect the pumping activity of many filter-feeding animals, possibly due to both the existence of a 'lower trigger level', below which the animals shut down, and an 'upper satiation concentration', above which the filtration activity is decreased (Riisgård \& Larsen 1995, 2000). It is currently being debated whether the filter-pumps of benthic macroinvertebrates are in general adapted for continuous operation at a characteristic high and constant rate adapted to the prevailing ambient phytoplankton concentrations, which implies that the clearance capacity is exploited within a certain range of algal concentrations (Jørgensen 1990, 1996 Clausen \& Riisgård 1996), or whether the animals are physiologically regulating their food intake by controlling the filtration rate according to quantity and food value of suspended particles in the water (Hawkins \& Bayne 1992, Bayne 1998, but see Riisgård 2001). Seen in this perspective, it is of interest to make a comparative study of waterprocessing in 2 ciliary filter-feeding polychaetes, the serpulid Ditrupa arietina from the Mediterranean Sea and the sabellid Euchone papillosa from the Gullmarsfjord, Sweden.

The Gulf of Lions is oligotrophic with low phytoplankton concentrations in the water column $(<1 \mu \mathrm{g}$ chlorophyll $\mathrm{a}^{-1}$ ) except during a spring bloom of about 2 wk (Jacques 1970). The Liguro-Provençal current restricts the influence of the Rhône River to the continental shelf, resulting in high turbidity. During winter, this trend is amplified by easterly storms enhancing sediment resuspension (Grémare et al. 1997). In the Gulf of Lions, the phytoplankton supply to benthic filter-feeders is in general limited and mixed with inorganic material.

The water of the Gullmarsfjord is stratified, with a brackish surface layer above the halocline at about $15 \mathrm{~m}$ and oceanic water ( $34 \mathrm{psu} 6$ to $12^{\circ} \mathrm{C}$ ) below. A spring bloom usually occurs in March with phytoplankton concentrations between 15 and $25 \mu \mathrm{g}$ chlorophyll $a \mathrm{l}^{-1}$. In summer, the chlorophyll a (chl a) concentrations are around $4 \mu \mathrm{g} \mathrm{l}^{-1}$, but may increase in the autumn to concentrations similar to that in spring (Lindahl \& Hernroth 1988). In 1985 and 1986, the annual organic carbon sedimentation at $60 \mathrm{~m}$ depth in the Gullmarsfjord was estimated to be $160 \mathrm{~g} \mathrm{~m}^{-2}$.

Besides possible adaptations of clearance rates to different environmental conditions, it was of interest to study the basic particle-capture mechanism and to reveal if common trends exist across taxonomic boundaries when relating performances to morphological characteristics such as volume of water being processed per unit of length of the ciliary bands.

The present work deals primarily with feeding rates and structures in Ditrupa arietina and Euchone papillosa in a comparative study, but video-microscope ob- 
servations of the particle-capture process in the latter have also been made. Finally, comparison with other taxonomic groups of ciliary filter-feeding marine animals forms part of this work.

\section{MATERIALS AND METHODS}

Collection of polychaetes. Specimens of the sabellid polychaete Euchone papillosa (Sars) were collected on 6 March 2000 at $75 \mathrm{~m}$ depth in the Gullmarsfjord on the Swedish west coast $\left(58^{\circ} 22.7^{\prime} \mathrm{N}, 11^{\circ} 36.3^{\prime} \mathrm{E}\right)$ by means of a USNEL spade-corer $(700 \mathrm{~kg})$ inside which transparent Plexiglas boxes $(47 \times 47 \mathrm{~cm}$, height $39 \mathrm{~cm})$ were installed before each deployment. The sediment core with almost intact fauna was brought to the nearby Kristineberg Marine Research Station and placed in an $8^{\circ} \mathrm{C}$ thermo-constant room, with running seawater $\left(34 \mathrm{psu}_{i} 14^{\circ} \mathrm{C}\right)$, and kept until the start of the experiments. The number of E. papillosa in each box was between 20 and 50 .

Specimens of the serpulid polychaete Ditrupa arietina (Müller) were dredged during early October 2000 from $20 \mathrm{~m}$ depth in the Bay of Banyuls-sur-Mer (Gulf of Lions, northwestern Mediterranean Sea, $38 \mathrm{psu} 1^{\circ} \mathrm{C}$ ). The worms were kept in the laboratory for a couple of days before being packed in sealed plastic bags with seawater and air and taken to Kristineberg Marine Research Station, where all clearance measurements were performed during late October 2000. The worms were kept for several days in running deep ambient seawater $\left(34 \mathrm{psu}_{i} 14^{\circ} \mathrm{C}\right)$ before being used in clearance experiments.

Clearance measurements. The clearance rate was measured as the volume of water cleared of $6 \mu \mathrm{m}$ diameter flagellate cells (Rhodomonas sp.) per unit time. Algal cells from a fast-growing batch culture were added to a well-mixed aquarium $(20 \times 19.2 \times$ $9.2 \mathrm{~cm}$ ) with a known volume of water $(V)$ and with a group of filter-feeding worms. Clearance measurements on Euchone papillosa were performed with a group of 16 worms placed individually in a glass-tube holder on the bottom of an aerated aquarium $\left(8^{\circ} \mathrm{C}\right)$ with seawater and added algal cells. Clearance measurements on Ditrupa arietina were performed with a group of 100 worms placed individually in vertical position in holes drilled in a PVC block, which was placed on the bottom of a strongly aerated aquarium $\left(14.5^{\circ} \mathrm{C}\right)$.

The reduction in the number of algal cells as a function of time was followed by taking samples $(15 \mathrm{ml})$ every 10 to $15 \mathrm{~min}$ and measuring the algal concentration with an electronic particle counter (Elzone model 80 xy fitted with a $76 \mu \mathrm{m}$ orifice tube). After measurement, the remaining water (about $13 \mathrm{ml}$ ) was immedi- ately returned to the experimental aquarium to ensure only an insignificant reduction in the total volume of water. The clearance rate was determined from the exponential reduction in the algal cell concentration. The slope of the estimated regression line describing the natural logarithm (ln) of the algal concentration as a function of time $(t)$, as well as the slope of the regression line in a control experiment without worms, were used for estimating the individual clearance rate as: $C l$ $\left(\mathrm{ml} \mathrm{h}^{-1}\right.$ ind $\left.^{-1}\right)=($ slope of regression line for aquarium with grazing worms - slope of regression line for control aquarium) $\times V(\mathrm{ml}) \times 60 / n$, where $n=$ mean number of actively filter-feeding (tentacle crown extended) worms noted each time a sample was taken during the experiment.

After the experiments, the sizes of individual worms or groups of worms were expressed in several ways: body and crown length were measured within a capillary glass tube held under a stereomicroscope, wet weight (worms taken out of their tubes and adhering water sucked up on paper), dry weight $\left(95^{\circ} \mathrm{C}\right.$ in a oven, $48 \mathrm{~h}$ ), and ash-free dry weight (AFDW: $4 \mathrm{~h}$ ashing of dry weight samples in a muffle furnace at $500^{\circ} \mathrm{C}$ ). Sample weights were determined on a microbalance (in $\mathrm{g}$ to 4 decimal places).

Video observations. The particle-capture process in Euchone papillosa was recorded using a video camera (Kappa CF 11/1) attached to a microscope (Nikon with depth of focus of $60 \mu \mathrm{m}$ at $40 \times$ magnification), and a 50 half-frames per second video recorder (Panasonic NVFS200 HQ). An intact worm in its tube was fixed on the tip of a movable rod (rotational and translational) in a horizontal position about $1 \mathrm{~cm}$ from the bottom in a $10 \times 10 \mathrm{~cm}$ Perspex observation chamber filled with seawater to a level of $2 \mathrm{~cm}$. The chamber was placed on the microscope with the cross-table removed so that the microscope objective could be immersed into the water above the crown, which was illuminated through a thin glass window in the bottom of the chamber. The objective was far enough (6 to $7 \mathrm{~mm}$ ) from the tentacles to not affect the rate and direction of flows. The seawater in the observation chamber contained $6 \mu \mathrm{m}$ diameter flagellates (Rhodomonas sp.) at a concentration of about 3000 cells $\mathrm{ml}^{-1}$. All observations were made at about $14^{\circ} \mathrm{C}$ during May 1999 at Kristineberg Marine Research Station. Captures of particles were traced from their position in successive video frames. The movements were followed by mounting a transparent plastic sheet onto the video screen so that the position of suspended particles could be marked with a pen directly on the sheet, frame by frame. Video pictures could also be copied by means of a video graphic printer (Sony UP-860 CE).

Electron microscopy. Specimens used for scanning electron microscopy (SEM) were narcotised with co- 


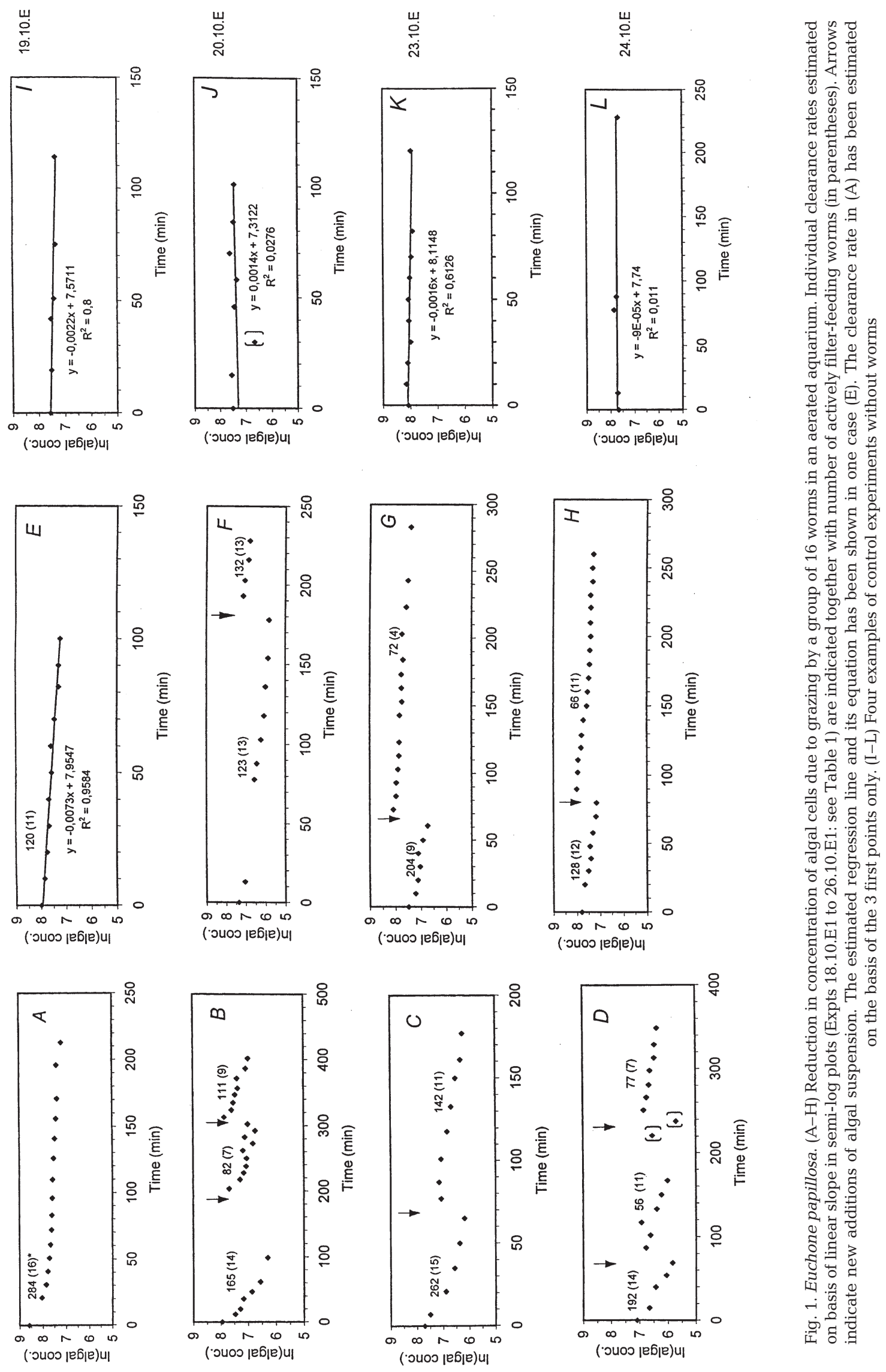


caine or $7.5 \% \mathrm{MgCl}_{2}$ in distilled water, fixed in 1 to $2 \%$ $\mathrm{OsO}_{4}$ in distilled water, dehydrated in an acetone series, and critical-point-dried (Nielsen 1987). Positions and length of the cilia were studied on the micrographs.

\section{RESULTS}

The reduction in algal concentration due to grazing by Euchone papillosa is shown in Figs. 1 \& 2 together with examples of control experiments without worms. Individual clearance rates, estimated on the basis of slope of regression lines, are indicated together with number of active worms. Table 1 gives a summary of the experimental conditions and the measured clearance rates in all experiments performed with E. papillosa.

The reduction in algal concentration due to filterfeeding by a group of 100 Ditrupa arietina, and due to sedimentation in a control aquarium without worms, is shown in Fig. 3. The individual clearance rates are indicated together with number of actively filter-feeding worms. Table 2 summarises the experimental conditions and the measured clearance rate in all experiments with $D$. arietina, and indicates volume of water in the aquarium, initial and final algal concentration, slope of estimated regression lines, number of algal
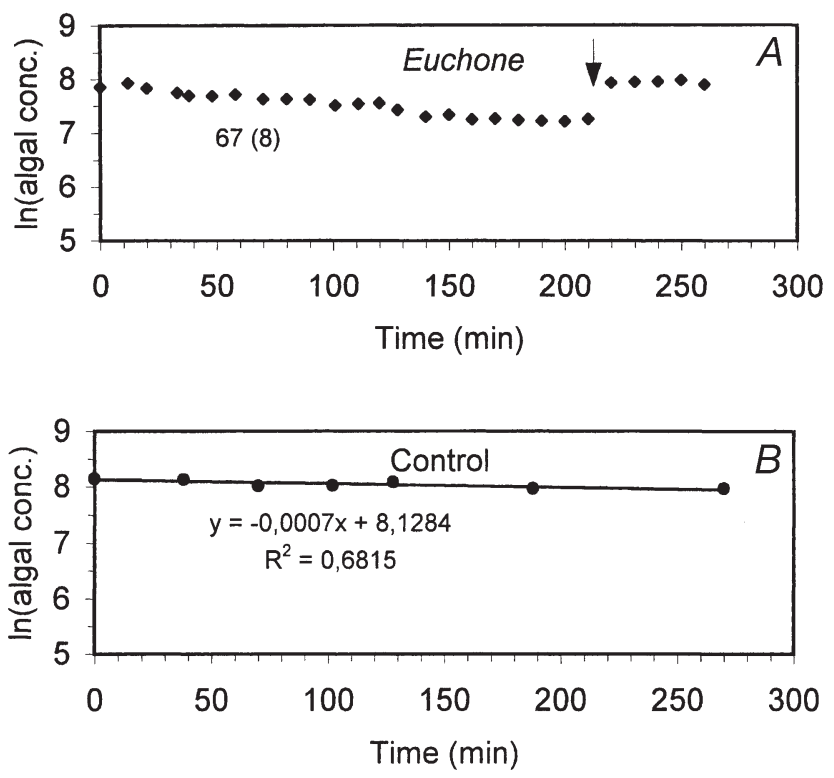

Fig. 2. Euchone papillosa. (A) Reduction in concentration of algal cells due to grazing by a group of 8 worms in an aerated aquarium. The individual clearance rate estimated on basis of linear slope in semi-log plot of first period after initial algal addition (Table 1: Expt 26.10.E2) is indicated together with number of actively filter-feeding worms (in parentheses). Arrow indicates new addition of algal suspension. (B) Control experiment without worms

Table 1. Euchone papillosa. Summary of clearance experiments with a group of 16 worms $\left(8^{\circ} \mathrm{C}\right)$. Volume of water in aquarium, initial and final algal (Rhodomonas sp.) concentration, slope of regression line in plot of ln(algal conc.) as a function of time (cf. Figs. 1A-H \& $2 \mathrm{~A}$ ), determination coefficient $\left(\mathrm{r}^{2}\right)$ and associated probability level (p), slope of regression line in control experiment without worms (cf. Fig. 1I-L), number of algal additions to aquarium during the experiment, number of actively filter-feeding worms (tentacle extended), and individual clearance rate are shown for all experiments; $95 \%$ confidence intervals (CI) for clearance rates (computed on the basis of confidence limits of the slope of the semilogarithmic regression models linking algal concentration and time in each experiments) are indicated in parentheses; ns: slope not statistically different from zero $(\mathrm{p}>0.05)$

\begin{tabular}{|c|c|c|c|c|c|c|c|c|c|c|}
\hline Expt (Fig.) & $\begin{array}{l}\text { Vol. } \\
(\mathrm{ml})\end{array}$ & $\begin{array}{c}\text { Initial } \\
\text { concentration } \\
\left(\text { cells ml }{ }^{-1} \text { ) }\right.\end{array}$ & $\begin{array}{c}\text { Final } \\
\text { concentration } \\
\left(\text { cells ml }{ }^{-1} \text { ) }\right.\end{array}$ & $r^{2}$ & $\mathrm{p}$ & $\begin{array}{l}\text { Slope of } \\
\text { regression line }\end{array}$ & $\begin{array}{l}\text { Slope } \\
\text { control }\end{array}$ & $\begin{array}{l}\text { Algal } \\
\text { addition }\end{array}$ & $\begin{array}{l}\text { Active } \\
\text { worms }\end{array}$ & $\begin{array}{c}\text { Clearance rate } \\
(95 \% \mathrm{CI}) \\
\left(\mathrm{ml} \mathrm{h}^{-1} \text { ind. }^{-1}\right)\end{array}$ \\
\hline 18.10.E1 (Fig. 1A) & 3078 & 5410 & 1320 & 0.994 & 0.048 & $-0.0241^{\mathrm{a}}$ & No control & 1 & 16 & $284(13-555)$ \\
\hline \multirow[t]{3}{*}{ 19.10.E1 (Fig. 1B) } & 2685 & 2810 & 545 & 0.928 & $<0.001$ & -0.0161 & -0.00218 & 1 & 14 & $165(104-226)$ \\
\hline & & 2180 & 1100 & 0.598 & 0.009 & -0.0061 & & 2 & 7 & $82(0-167)$ \\
\hline & & 2595 & 1080 & 0.925 & $<0.001$ & -0.0087 & & 3 & 9 & $111(69-154)$ \\
\hline \multirow[t]{2}{*}{ 20.10.E1 (Fig. 1C) } & 2685 & 2250 & 480 & 0.941 & 0.001 & -0.0241 & ns & 1 & 15 & $262(171-353)$ \\
\hline & & 1180 & 520 & 0.959 & $<0.001$ & -0.0096 & & 2 & 11 & $142(113-171)$ \\
\hline \multirow[t]{3}{*}{ 21.10.E1 (Fig. 1D) } & 2907 & 1210 & 345 & 0.971 & 0.002 & -0.0173 & -0.00165 & 1 & 14 & $192(125-260)$ \\
\hline & & 875 & 300 & 0.502 & 0.049 & -0.0053 & & 2 & 11 & $56(0-136)$ \\
\hline & & 930 & 580 & 0.971 & $<0.001$ & -0.0048 & & 3 & 7 & $77(54-100)$ \\
\hline 23.10.E1 (Fig. 1E) & 3076 & 3010 & 1820 & 0.958 & $<0.001$ & -0.0073 & -0.00162 & 1 & 11 & $93(74-112)$ \\
\hline \multirow[t]{2}{*}{ 24.19.E1 (Fig. 1F) } & 3076 & 1590 & 340 & 0.967 & $<0.001$ & -0.0089 & ns & 1 & 13 & $123(101-145)$ \\
\hline & & 1240 & 890 & 0.974 & 0.013 & -0.0095 & & 2 & 13 & $132(48-216)$ \\
\hline \multirow[t]{2}{*}{ 25.10.E1 (Fig. 1G) } & 3196 & 1810 & 840 & 0.878 & 0.002 & -0.0103 & -0.00115 & 1 & 9 & $204(105-302)$ \\
\hline & & 3230 & 1660 & 0.955 & $<0.001$ & -0.0028 & & 2 & 4 & $72(56-88)$ \\
\hline \multirow[t]{2}{*}{ 26.10.E1 (Fig. 1H) } & 3197 & 2455 & 1280 & 0.965 & $<0.001$ & -0.0084 & -0.00066 & 1 & 12 & $128(102-154)$ \\
\hline & & 3000 & 1450 & 0.904 & $<0.001$ & -0.0043 & & 2 & 11 & $66(53-80)$ \\
\hline 26.10.E2 (Fig. 2) & 3320 & 2570 & 1430 & 0.948 & $<0.001$ & -0.0034 & -0.00066 & 1 & 8 & $67(58-76)$ \\
\hline
\end{tabular}



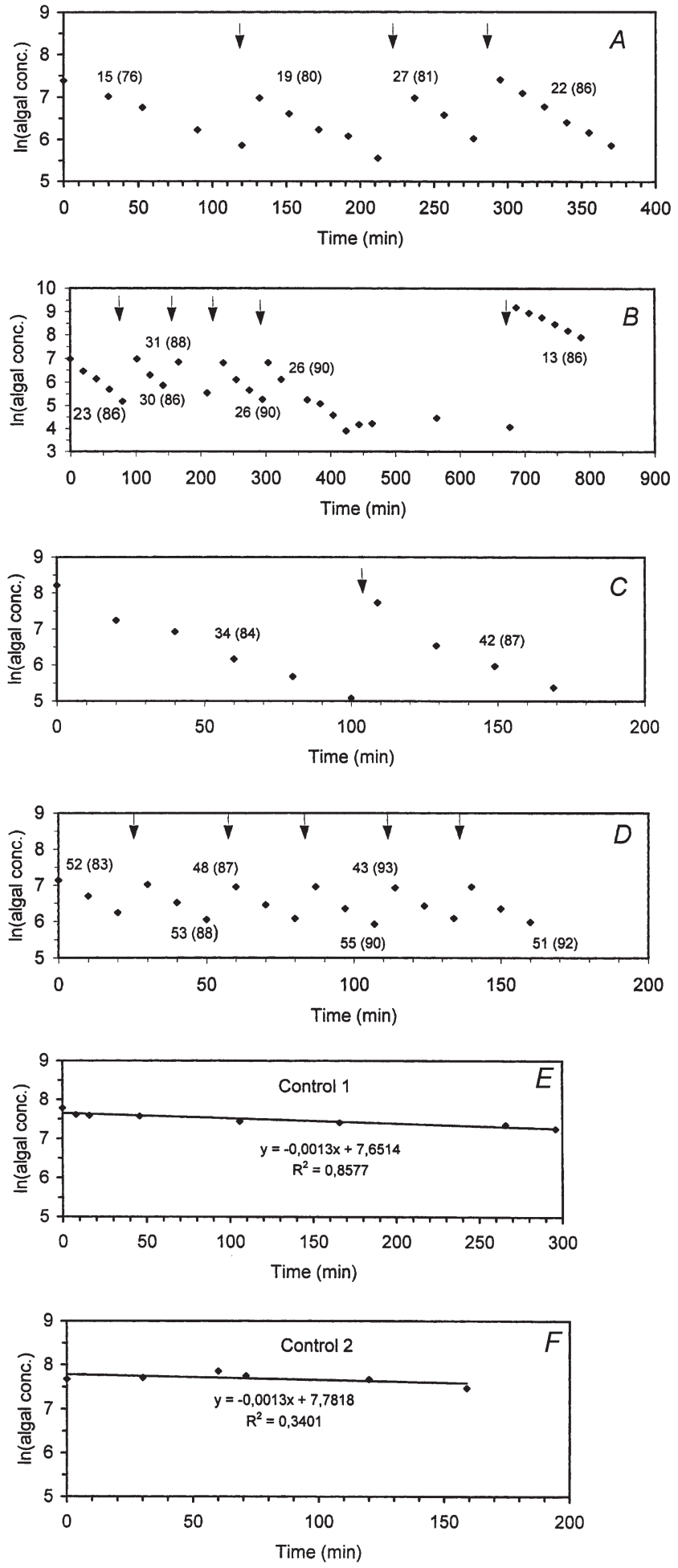

Fig. 3. Ditrupa arietina. (A-D) Reduction in concentration of algal cells due to grazing by a group of 100 worms in an aerated aquarium. Individual clearance rates estimated on basis of linear slope in semi-log plots (Expts 20.10.D to 24.10.D: see Table 2) are indicated together with number of actively (crown tentacle extended) filter-feeding worms (in parentheses). Arrows indicate new additions of algal suspension.

$(\mathrm{E}, \mathrm{F})$ Examples of control experiments without worms additions, and mean number of actively filter-feeding worms during each experiment.

Table 3 compares the tentacle crown parameters described in Fig. 4 and the clearance rates of Euchone papillosa and Ditrupa arietina. The clearance rate of a 'standard' $1.5 \mathrm{mg}$ dry wt E. papillosa is shown both as the mean of all measurements after the first algal addition, and (in parentheses in Table 3) as the mean of all measurements after the second and third algal additions (Table 1); this was done because of a trend to lower rates during an experiment, possibly due to increasing satiation. The clearance rate of a 'standard' $3.0 \mathrm{mg}$ dry wt $D$. arietina is shown both as the mean of all measurements (except for Expt 21.10.D5, in which the high algal concentration obviously satiated the worms) and (in parentheses) as the mean of all rates measured in the last 2 series (23.10.D and 24.10.D: Table 2); this was done because of a trend to higher rates with increasing acclimation time in the laboratory. It is seen that the clearance rate per centimetre of ciliary band was 0.2 to $0.4 \mathrm{ml} \mathrm{h}^{-1} \mathrm{~cm}^{-1}$ for E. papillosa and slightly higher $\left(0.4\right.$ to $\left.0.6 \mathrm{ml} \mathrm{h}^{-1}\right) \mathrm{cm}^{-1}$ for $D$. arietina. The maximum weight-specific clearance rate was $114.7 \mathrm{ml} \mathrm{h}^{-1} \mathrm{mg}^{-1}$ for E. papillosa and about 7 times lower $\left(15.7 \mathrm{ml} \mathrm{h}^{-1} \mathrm{mg}^{-1}\right)$ for $D$. arietina. The body mass and length of the 2 worms are shown in Table 4.

Examples of particle capture by Euchone papillosa are shown in Fig. 5. Particles approaching the pinnules with the upstream water suddenly accelerate and move through an arc of over $180^{\circ}$ to be delivered on the frontal side of the pinnule and then transported toward the mouth. The velocity component of particle motion in the plane recorded ranged from upstream values of about $0.5 \mathrm{~mm} \mathrm{~s}^{-1}$ (i.e. the particle moved about $10 \mu \mathrm{m}$ between 2 video frames separated by $1 / 50 \mathrm{~s}$ ) to maximum values of 0.8 to $0.9 \mathrm{~mm} \mathrm{~s}^{-1}$ during transfer, to about $0.2 \mathrm{~mm} \mathrm{~s}^{-1}$ during transport on the frontal side of the pinnule. At locations of maximum velocity, particle images were blurred to the extent of about 2 particle diameters. During transfer, particles have a velocity component normal to the plane recorded and, assuming a path forming an angle of $45^{\circ}$ with the normal, actual maximum velocities may be 2 times those observed. Fig. $5 \mathrm{c}$ shows that transfer takes place at a maximum distance (radius) of about $25 \mu \mathrm{m}$ from the pinnule. The examples given in Fig. 5 show how particles approaching a pinnule with the upstream water (particles with broken outlines in Fig. 5) come into focus in the microscope, whereupon the particles are caught up by the lateral cilia and transferred to the frontal side of the tentacle.

The scanning micrographs show the compound lateral cilia to be 20 to $25 \mu \mathrm{m}$ long in both Ditrupa arietina and Euchone papillosa and to consist of 1 row of 4 cilia (Fig. 6). In E. papillosa a series of compound, possibly sensory, cilia were observed just abfrontal to the lateral ciliary band. 
Table 2. Ditrupa arietina. Summary of clearance experiments with 100 worms $\left(14.5^{\circ} \mathrm{C}\right)$. For different series of experiments are indicated volume of water in the aquarium, initial and final algal (Rhodomonas sp.) concentration, slope of regression line in plot of ln(algal conc.) as a function of time (cf. Fig. 3A-D), determination coefficient $\left(\mathrm{r}^{2}\right)$ and associated probability level (p), regression slope of regression line in control experiments without worms (cf. Fig. 3E,F), number of algal additions made during the experiment, number of actively filter-feeding worms (tentacle crown extended), and individual clearance rate are shown for all experiments. $95 \%$ confidence intervals (CI) on clearance rates are indicated in parentheses

\begin{tabular}{|c|c|c|c|c|c|c|c|c|c|c|}
\hline $\begin{array}{l}\text { Exp. } \\
\text { (Fig.) }\end{array}$ & $\begin{array}{l}\text { Volume } \\
\text { (ml) }\end{array}$ & $\begin{array}{c}\text { Initial } \\
\text { conc. } \\
\left(\text { cells ml }{ }^{-1}\right)\end{array}$ & $\begin{array}{c}\text { Final } \\
\text { conc. } \\
\left(\text { cells ml }{ }^{-1}\right)\end{array}$ & $\begin{array}{l}\text { Slope of } \\
\text { regression } \\
\text { line }\end{array}$ & $r^{2}$ & $\mathrm{p}$ & $\begin{array}{l}\text { Slope } \\
\text { control }\end{array}$ & $\begin{array}{c}\text { Algal } \\
\text { addition }\end{array}$ & $\begin{array}{l}\text { Active } \\
\text { worms }\end{array}$ & $\begin{array}{c}\text { Clearance rate } \\
(95 \% \mathrm{CI}) \\
\left(\mathrm{ml} \mathrm{h}^{-1} \text { ind }^{-1}\right)\end{array}$ \\
\hline \multirow[t]{4}{*}{ 20.10.D (Fig. 3A) } & \multirow[t]{4}{*}{1620} & 1620 & 350 & -0.0128 & 0.992 & $<0.001$ & \multirow[t]{4}{*}{-0.0012} & 1 & 76 & $15(14-16)$ \\
\hline & & 1070 & 260 & -0.0168 & 0.999 & $<0.001$ & & 2 & 80 & $19(14-24)$ \\
\hline & & 1070 & 415 & -0.0238 & 0.999 & 0.012 & & 3 & 81 & $27(0-63)$ \\
\hline & & 1640 & 350 & -0.0206 & 0.998 & $<0.001$ & & 4 & 86 & $22(20-23)$ \\
\hline \multirow[t]{6}{*}{ 21.10.D (Fig. 3B) } & \multirow[t]{6}{*}{1630} & 640 & 180 & -0.0219 & 0.995 & $<0.001$ & \multirow[t]{6}{*}{-0.0016} & 1 & 86 & $23(20-26)$ \\
\hline & & 1080 & 350 & -0.0281 & 0.984 & 0.080 & & 2 & 86 & $30(0-81)$ \\
\hline & & 950 & 255 & -0.0298 & 0.978 & & & 3 & 88 & 31 \\
\hline & & 910 & 190 & -0.0255 & 0.978 & 0.011 & & 4 & 90 & $26(13-39)$ \\
\hline & & 920 & 190 & -0.0257 & 0.981 & 0.087 & & 5 & 90 & $26(0-75)$ \\
\hline & & 9885 & 2740 & -0.0128 & 0.996 & $<0.001$ & & 6 & 86 & $13(12-14)$ \\
\hline \multirow[t]{2}{*}{ 23.10.D (Fig. 3C) } & 1630 & 3700 & 160 & -0.0301 & 0.987 & $<0.001$ & \multirow[t]{2}{*}{-0.0009} & 1 & 84 & $34(31-43)$ \\
\hline & & 2290 & 220 & -0.0382 & 0.962 & 0.019 & & 2 & 87 & $42(18-73)$ \\
\hline \multirow[t]{6}{*}{ 24.10.D (Fig. 3D) } & 1760 & 1260 & 515 & -0.0448 & 0.999 & 0.009 & \multirow[t]{6}{*}{-0.0012} & 1 & 83 & $52(42-61)$ \\
\hline & & 1125 & 420 & -0.0488 & 0.999 & 0.015 & & 2 & 88 & $53(36-70)$ \\
\hline & & 1050 & 440 & -0.0436 & 0.999 & 0.049 & & 3 & 87 & $48(0-96)$ \\
\hline & & 1960 & 375 & -0.0520 & 0.990 & 0.064 & & 4 & 90 & $55(0-128)$ \\
\hline & & 1030 & 440 & -0.0424 & 0.988 & 0.069 & & 5 & 93 & $43(0-105)$ \\
\hline & & 1050 & 400 & -0.0488 & 0.981 & 0.088 & & 6 & 92 & $51(0-142)$ \\
\hline
\end{tabular}

\section{DISCUSSION}

\section{Video observations}

The paths and velocities of particles indicate that particle velocity accelerates with the water that enters the region swept by the compound lateral cilia, and the particles are then caught up by 1 or possibly more of the compound cilia (Fig. 6) during their power stroke (Fig. 5). This accelerates a particle and rapidly moves it in a curved path to the midline at the frontal side of the pinnule. At this stage of the power stroke, the particle is pushed out of the main water current which moves past the pinnule, and as the compound lateral cilia come to rest so does the particle. Downstream-collecting has been observed in larvae of gastropods, bivalves, polychaetes, and entoprocts and in adult sabellid and serpulid polychaetes, entoprocts, and some rotifers (for reviews see Nielsen 1987 and Riisgård et al. 2000).

\section{Clearance experiments}

Some differences and similarities between the 2 ciliary filter-feeding polychaetes Euchone papillosa and Ditrupa arietina are apparent. The ciliary lengthspecific clearance rates are very similar, about 0.4 to $0.6 \mathrm{ml} \mathrm{h}^{-1} \mathrm{~cm}^{-1}$ (Table 3).
Table 3. Euchone papillosa and Ditrupa arietina. Comparison of tentacle crown variables (Fig. 4) and water-processing. Clearance rate of a 'standard' E. papillosa is shown both as the mean $( \pm \mathrm{SD})$ of all measurements after first algal addition, and (in parentheses) as the mean of all measurements after a second and third algal addition (Table 1). Clearance rate of a 'standard' $D$. arietina is shown both as the mean of all measurements (except for Expt 21.10.D5) and (in parentheses) as the mean of all rates measured in the last 2 series, 23.10.D and 24.10.D (Table 2)

\begin{tabular}{|c|c|c|}
\hline Variable & $\begin{array}{l}\text { Euchone } \\
\text { papillosa }\end{array}$ & $\begin{array}{l}\text { Ditrupa } \\
\text { arietina }\end{array}$ \\
\hline Number of tentacles & 18 & 25 \\
\hline Length of tentacles (mm) & 6.9 & 2.0 \\
\hline $\begin{array}{l}\text { Number of pinnules } \\
\text { per tentacle }\end{array}$ & 80 & 68 \\
\hline Length of pinnules (mm) & 1.53 & 0.25 \\
\hline $\begin{array}{l}\text { Total length of lateral } \\
\text { ciliary band }(L, \mathrm{~cm})\end{array}$ & 441 & 85 \\
\hline Temperature $\left({ }^{\circ} \mathrm{C}\right)$ & 8 & 14 \\
\hline $\begin{array}{l}\text { Clearance rate of 'standard' } \\
\text { worm }\left(F, \mathrm{ml} \mathrm{h}^{-1}\right)\end{array}$ & $172 \pm 71(92 \pm 32)$ & $47 \pm 7(35 \pm 13)$ \\
\hline $\begin{array}{l}\text { Dry weight of 'standard' } \\
\text { worm }(W, \mathrm{mg})\end{array}$ & 1.5 & 3.0 \\
\hline $\begin{array}{l}\text { Ciliary length-specific } \\
\text { clearance rate } \\
\left(F / L, \mathrm{ml} \mathrm{h}^{-1} \mathrm{~cm}^{-1}\right)\end{array}$ & $0.4(0.2)$ & $0.6(0.4)$ \\
\hline $\begin{array}{l}\text { Weight-specific } \\
\text { clearance rate } \\
\left(F / W, \mathrm{ml} \mathrm{h}^{-1} \mathrm{mg}^{-1}\right)\end{array}$ & $114.7(61.3)$ & $15.7(11.7)$ \\
\hline
\end{tabular}




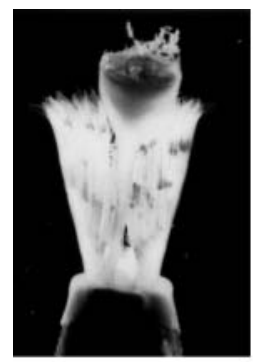

$A$
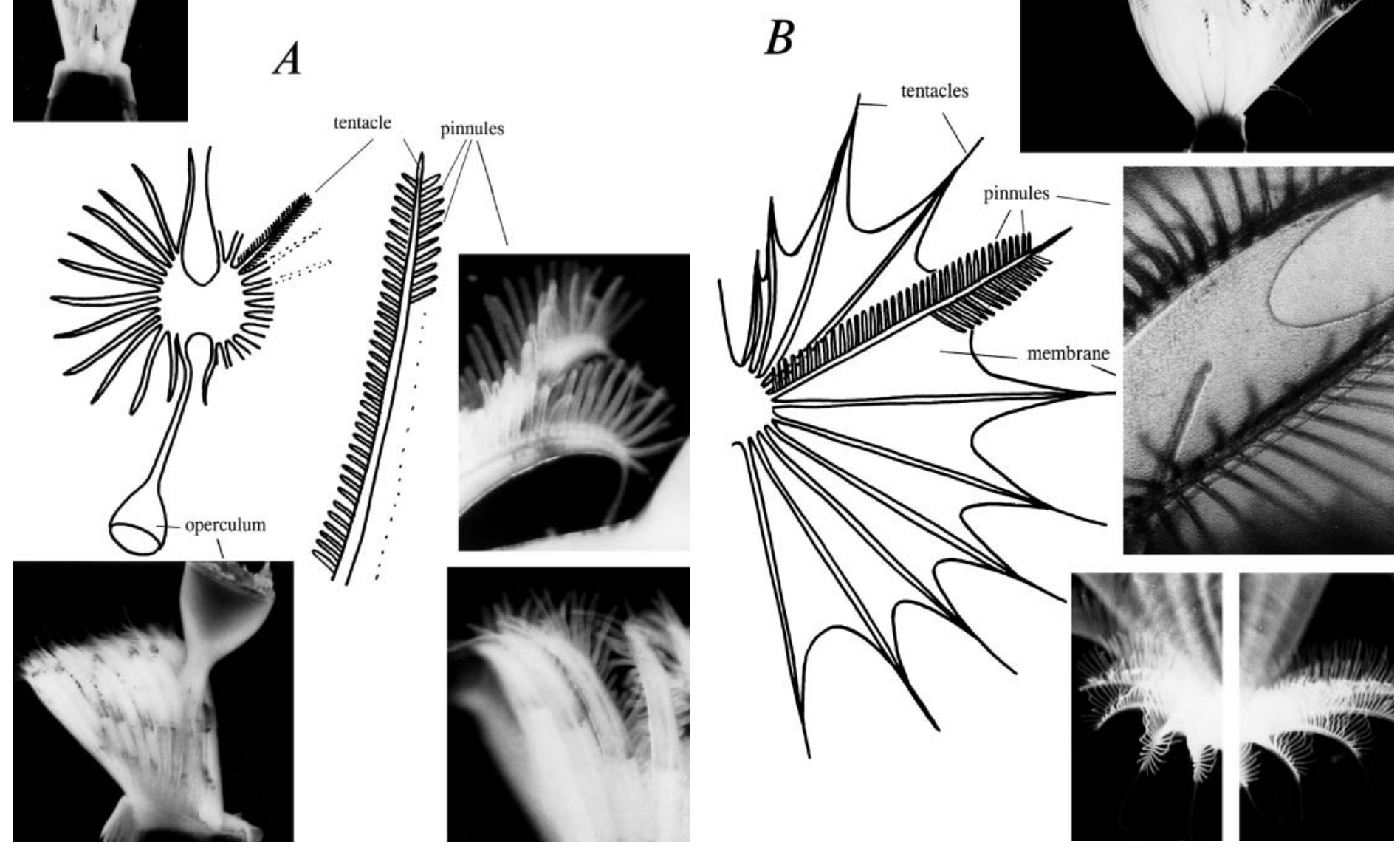

$B$

Fig. 4. (A) Ditrupa arietina. Video-graph pictures and sketch of serpulid tentacle crown and individual filament with 2 rows of pinnules; mean number of tentacles (length $=2 \mathrm{~mm}$ ) is 25 (varies between 22 to 28); mean number of pinnules (diameter $=0.025 \mathrm{~mm}$, length $=0.25 \mathrm{~mm}$ ) on the bi-pinnate tentacles is 68 ; total length of the ciliary band on each lateral side of the pinnules is estimated at $25 \times 68 \times 0.25 \times 2=850 \mathrm{~mm}$ (Table 3 ). (B) Euchone papillosa. Video-graph pictures and sketch of sabellid crown with tentacles and pinnules; the crown, which is webbed with a thin membrane for 2-thirds of its length, consists of 22 filaments, namely 18 bi-pinnate (diameter $=0.637 \mathrm{~mm}$, length $=6.9 \mathrm{~mm}$ ) with tapered tips, and 4 apinnate; a pinnate filament has 2 rows, each with 40 pinnules; each pinnule (diameter $=26 \mu \mathrm{m}$, length $=1.53 \mathrm{~mm}$ ) has 2 rows of ciliary bands; total length of the water pumping ciliary band is estimated at $18 \times 80 \times 1.53 \times 2=4406 \mathrm{~mm}$ (Table 3 )

Because cilia are cell organelles that may be expected to have some basic characteristics in common across taxonomic boundaries, a comparison of the existing knowledge seems appropriate (Table 5). The volume of water cleared by a ciliary filter-feeder is determined by the beat frequency, the width, the length of the cilia, and the distance between neighbouring cilia. It is interesting to note that the lateral cilia, which pump water through some kind of a filter (e.g. mucus net in ascidians and lancelets, ciliary sieve in bryozoans, cirri trap in mussels: Larsen \& Riisgård 1995, 2000, Riisgård et al. 2000), have comparable water-processing performances, usually in the range of 0.3 to $0.6 \mathrm{ml} \mathrm{h}^{-1} \mathrm{~cm}^{-1}$ of ciliary band. Echinoderms (in which the method of sus- pension-feeding by ciliated bands is not yet fully understood: Hart 1991) and veliger larvae and polychaetes (both with water-pumping and particle-capturing compound cilia) also fall within this range of performance. The significance of this remarkable uniformity remains to be explained in deeper detail.

It is striking that the maximum weight-specific clearance rate is about 7 times higher in Euchone papillosa than in Ditrupa arietina (Table 3). The hypothesis of 'minimal scaling' implies that energy for functions other than pump work can only be justified when that part of the organism responsible for the pumping action is dimensioned for continous feeding (Jørgensen 1975, Clausen \& Riisgård 1996, Riisgård \& 
Goldson 1997, Riisgård \& Larsen 2000). Therefore, the relatively large tentacle crown in E. papillosa, resulting in a 7 times higher specific clearance rate, may be the evolutionary result of 'minimal scaling' and adaptation to extremely low food concentrations. The general trend for E. papillosa (Table 1), but not $D$. arietina (Table 2), to become satiated after a second algal addition to the experimental aquarium supports this interpretation. Use of high particle concentrations in earlier clearance experiments may explain the generally low values found for filter-feeding polychaetes by other workers (Dales 1957, 1961, Buhr 1976, Klöckner 1978, Shumway et al. 1988, Davies et al. 1989). For example, in a study of Lanice conchilega, Buhr (1976) used a Dunaliella marina algal concentration of 40000 cells ml- ${ }^{-1}$, which is more than 10 times above the 'satiation' concentration found for Sabella pavonina (Riisgård \& Ivarsson 1990) and for E. papillosa and $D$. arietina in the present work. Likewise, in a clearance study of the sabellid polychaete $M y x i-$ cola infundibulum, Shumway et al. (1988) used 17000 to 35000 algal cells $\mathrm{ml}^{-1}$.

In many marine filter-feeders there is a 'lower threshold' for phytoplankton concentration below which the animals reduce the filtration rate, e.g. mussels close their valves at concentrations below about

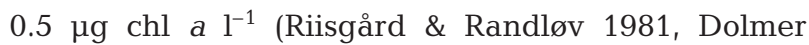
$2000 a, b)$; ascidians reduce the water-pumping ciliary activity in the openings of the branchial sac when the phytoplankton concentration is low (Petersen \& Riisgård 1992, Petersen et al. 1999), bryozoans shut down (Barnes \& Clarke 1994, Riisgård \& Goldson 1997), and the facultative filter-feeding Nereis diversicolor may switch to surface deposit feeding if the concentration of suspended food particles falls below a certain 'trigger level', (Vedel et al. 1994, Riisgård \& Kamermans 2001). No conspicuous tendency to reduce filter-feeding activity at even very low algal concentrations was noticed in the 2 polychaetes studied in the present work - apart from a tendency in Ditrupa arietina for an increase in the number of active individuals and in their individual clearance rate during the experimental period (Table 2), a phenomenon which may be ascribed to increasing adaptation to the laboratory conditions. The initial and final algal concentrations used in the clearance experiments appear in Tables $1 \& 2$. The relationship between chl a concentration ( $\mu \mathrm{g} \mathrm{chl} \mathrm{a}^{-1}$ ) and concentration of Rhodomonas sp. $\left(C, \times 10^{3}\right.$ cells $\left.\mathrm{ml}^{-1}\right)$ was determined by Clausen \& Riisgård (1996) as: chl $a=1.25 \times C$. Most experiments in the present work were conducted at algal concentrations equivalent to about 0.4 to $3.8 \mu \mathrm{g} \mathrm{chl} \mathrm{l}^{-1}$. These concentrations are comparable to phytoplankton biomass in natural waters. Thus, the median value for

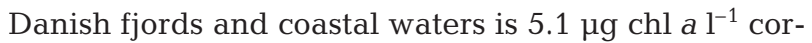
responding to 4000 Rhodomonas sp. cells ml ${ }^{-1}$ (SandJensen et al. 1994). The algal concentrations used in the present work appear to be relatively low compared to those in most coastal temperate waters, but the natural concentrations at the living sites of the 2 polychates are more appropriate references.

In the Bay of Banyuls-sur-Mer, chl a concentrations are minimal during summer (i.e. between 0.2 and $0.4 \mathrm{\mu g} \mathrm{l}^{-1}$ ) and maximal during the late winter/early spring bloom, when for shorts periods of time they can reach up to $5 \mathrm{\mu g} \mathrm{l}^{-1}$ (Jacques 1970, Jordana 2000). $\mathrm{Chl}$ a concentrations close to the sea bed in the immediate vicinity of field populations of Ditrupa arietina are usually $<1 \mu \mathrm{g} \mathrm{l}^{-1}$ (Jordana 2000), corresponding to $<800$ Rhodomonas sp. cells $\mathrm{ml}^{-1}$. Concentrations used in the present study may thus have been slightly higher than generally experienced by the worms during most of the year. This may explain the absence of a lower trigger level in $D$. arietina.

The chl a concentrations in surface water of the Gullmarsfjord are about $4 \mathrm{\mu g} \mathrm{l}^{-1}$ during summer, which is considerably higher than in the Bay of Banyuls-surMer. The sedimentation rate of particulate organic material (POM) during the winter and spring is about $0.5 \mathrm{~g}$ dry wt $\mathrm{m}^{-2} \mathrm{~d}^{-1}$, and during summer and early autumn the sedimentation rate varies between about 0.6 and $1.4 \mathrm{~g}$ dry wt $\mathrm{m}^{-2} \mathrm{~d}^{-1}$. The annual sedimentation of particulate organic carbon (POC) which may reach the deeper bottoms below the halocline is approximately $160 \mathrm{~g} \mathrm{~m}^{-2}$ (Lindahl 1988). The size and the ability of Euchone papillosa to utilise these particles is not known, but the following considerations may be useful as a first approach. Presuming that $1 \mathrm{ml} \mathrm{O}_{2} \approx 0.5 \mathrm{mg} \mathrm{POC} \approx 1 \mathrm{mg}$ 
(a)

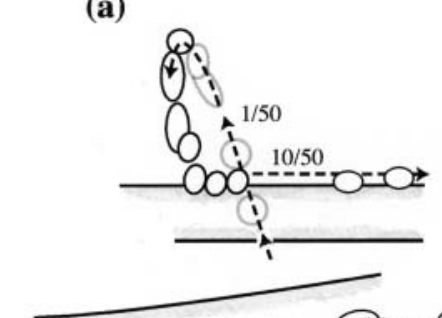

(b)
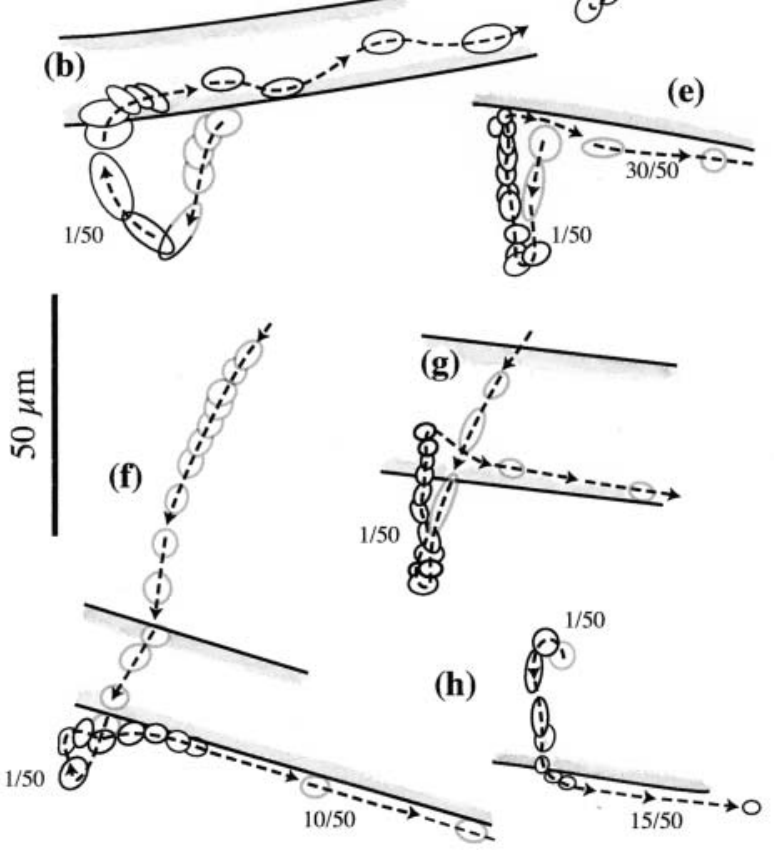

Fig. 5. Euchone papillosa. Examples of particle capture. Time interval between successive video frames are indicated $(1$ frame $=1 / 50 \mathrm{~s} ; 10$ frames $=10 / 50 \mathrm{~s})$. Particles approaching the pinnules accelerate and move through an $\operatorname{arc}$ of $180^{\circ}$ to the frontal side of the pinnule and are transported toward the mouth. Transfer takes place at a maximum distance of about $35 \mu \mathrm{m}$ from the pinnule $(\mathrm{C})$. Particles approaching a pinnule have broken outlines because they are out of microscope focus. At locations of maximum velocity, particle images were blurred to a length of about 2 particle diameters (about $12 \mu \mathrm{m}$ )
$\mathrm{POM} \approx 20 \mathrm{~J}$ (e.g. Gnaiger 1983, Smaal \& Widdows 1994), a sedimentation rate of $160 \mathrm{~g} \mathrm{POC} \mathrm{m}^{-2} \mathrm{yr}^{-1}$ would transfer $\left[160 \times 20000=3200 \mathrm{~kJ} \mathrm{~m}^{-2} \mathrm{yr}^{-1}=8767 \mathrm{~J} \mathrm{~m}^{-2} \mathrm{~d}^{-1}\right.$ $=] 0.877 \mathrm{~J} \mathrm{~cm}^{-2} \mathrm{~d}^{-1}$ down to the zoobenthos in the Gullmarsfjord. A rough estimate of the respiration rate $(R$, $\mathrm{ml} \mathrm{O}_{2} \mathrm{~h}^{-1}$ ) of a 'standard' (Table 4) $1.5 \mathrm{mg}$ dry wt E. papillosa obtained by from the equation $R=0.13 W$ (g dry wt) ${ }^{0.66}$ (applied to Sabella pavonina by Riisgård \& Ivarsson 1990) would be $\left[0.0018 \mathrm{ml} \mathrm{O}_{2} \mathrm{~h}^{-1}=0.036 \mathrm{~J} \mathrm{~h}^{-1}=\right]$ $0.864 \mathrm{~J} \mathrm{~d}^{-1}$, and by using $R=0.141 W^{0.668}$ (applied to the sabellid Myxicola infundibulum by Shumway et al. 1988) would be $0.879 \mathrm{~J} \mathrm{~d}^{-1}$. The area of the (usually horizontally placed) tentacle crown of an undisturbed 'standard' E. papillosa is $\left[\pi \times 0.63^{2}=\right] 1.25 \mathrm{~cm}^{2}$. The amount of POC falling down directly onto the tentacle crown is equivalent to [ $1.25 \times 0.877=] 1.1 \mathrm{~J} \mathrm{~d}^{-1}$, which is sufficient to cover the energy need of the worm if the assimilation efficiency of the ingested POC is about $80 \%$. However, it is unknown whether the POC is in a form available to the worms, with the particles of a suitable size to be captured and ingested, and the organic carbon digestible. If the food is mainly fresh phytoplankton the following considerations may be relevant: The energy content of a Rhodomonas sp. cell is $1.75 \mu \mathrm{J}$ (Kiørboe et al. 1985), which implies that the ingestion rate $(I)$ must be equivalent to $0.036 /\left(1.75 \times 10^{-6}\right)=$ 20570 cells $\mathrm{h}^{-1}$, which is possible if the mean algal concentration $=I /(C l)[=20570 / 172]=120$ cells ml $^{-1}$ (or $0.15 \mu \mathrm{g} \mathrm{chl} \mathrm{a}^{-1}$ ). A similar estimate for Ditrupa arietina results in a minimum algal concentration of 680 Rhodomonas sp. cells ml $\mathrm{m}^{-1}$ (or $0.85 \mu \mathrm{g} \mathrm{chl} \mathrm{a} \mathrm{l}^{-1}$ ).

Clearance studies by Riisgård \& Ivarsson (1990) on the ciliary filter-feeding polychaete Sabella pavonina showed that the clearance rate was high and constant for algal (Dunalilella marina and Rhodomonas sp.) concentrations ranging between about 2000 and 4000 cells $\mathrm{ml}^{-1}$. At concentrations $>4000$ cells $\mathrm{ml}^{-1}$ the clearance
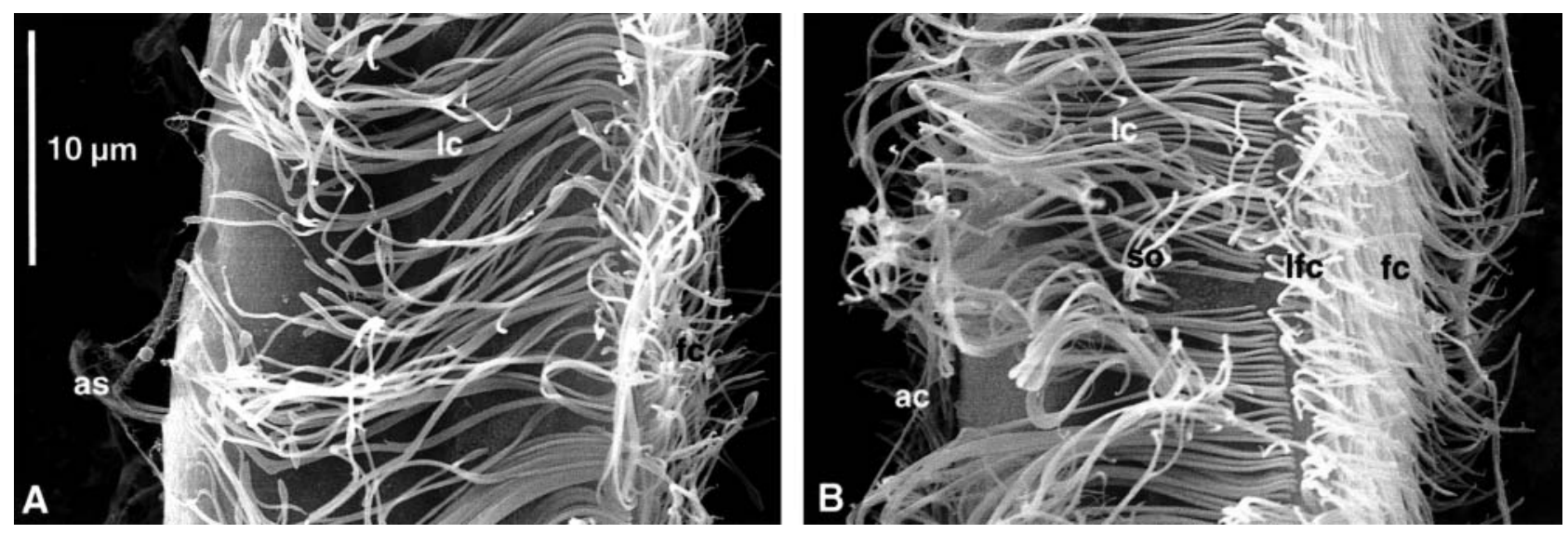

Fig. 6. Ditrupa arietina (A) and Euchone papillosa (B). Lateral views of pinnules, SEM. ac: abfrontal cilia; as: abfrontal sensory organ; fc: frontal cilia; lc: lateral (compound) cilia; lfc: laterofrontal cilia; so: sense organ 
rate was reduced, presumably because the gut capacity was exceeded. A similar phenomenon was found for Ditrupa arietina in the present work when the algal concentration was increased from about 2000 to nearly 10000 cells $\mathrm{ml}^{-1}$, which resulted in a $50 \%$ decrease in the clearance rate (from 26 to $13 \mathrm{ml} \mathrm{h}^{-1}$ ind. $^{-1}$, see Table 2: Expt 21.10.D). The Bay of Banyuls-sur-Mer is characterised by strong water movements, which can lead to transitory drastic increases in suspended particle concentration through sediment resuspension (Grémare et al. 1997, 1998a). The relatively high concentrations associated with the onset of satiation in $D$. arietina may be an adaptation to such a changing environment. As previously mentioned, there was a tendency for reduced clearance in Euchone papillosa after more than 1 algal addiditon. This indicates that the concentrations used in the experiments may have been higher than generally experienced by E. papillosa at its natural site. This once more emphasises the general need for more knowledge about actual algal concentrations in the immediate vicinity of filter-feeding zoobenthos (Vedel 1998, Dolmer 2000a,b, Riisgård \& Larsen 2000).

A realistic area-specific population-filtration capacity of Euchone papillosa and Ditrupa arietina may be estimated at [200 ind. $\mathrm{m}^{-2} \times 172 \mathrm{ml} \mathrm{h}^{-1}$ ind. $\left.{ }^{-1}\right]=0.8$ and [1000 ind. $\mathrm{m}^{-2} \times 47 \mathrm{ml} \mathrm{h}^{-1}$ ind..$\left.^{-1}\right]=1.1 \mathrm{~m}^{3}$ water $\mathrm{m}^{-2} \mathrm{~d}^{-1}$ respectively. In comparison, the population filtration rates in coastal waters where population filtration capacities are typically higher, between 1 and $10 \mathrm{~m}^{3}$ water $\mathrm{m}^{-2} \mathrm{~d}^{-1}$ (Lemmens et al. 1996, Riisgård \& Larsen 2000). Realisation of these estimated capacities is highly dependent on the filtering activity. Both worms are extremely sensitive to experimental conditions, and even the slightest disturbances cause them to immediately withdraw into their tubes. To judge from the present work, the filtering activity of both worms seems to be a basically continuous process. This is consistent with the previous observation of a positive correlation linking duration of individual filtration events and total time spent filtering in D. papillosa (Jordana et al. 2000), although it should be stressed that filtering activity may show seasonal changes related to the reproductive cycle and age structure of the population (Jordana et al. 2000), and that repetition of short filtration events may be associated with low filtering activity of the worms.

Acknowledgements. A.G., J.M.A., F.C. and G.V. (the 'French delegation') were supported by the Transnational Access to Major Research Infrastructures at Kristineberg Marine Research Station, Sweden, during a workshop in October 2000. Thanks are due to Birthe Hellman for technical assistance and to 3 anonymous referees and 1 who waived anonymity (Sjaak Lemmens) for constructive comments. Örjan Karlsson and Karin Hollertz often lent a helping hand during the experiments.

\section{LITERATURE CITED}

Barnes DKA, Clarke A (1994) Season variation in the feeding activity of four species of Antarctic bryozoan in relation to environmental factors. J Exp Mar Biol Ecol 181: 117-133

Bayne BL (1998) The physiology of suspension feeding by bivalve molluscs: an introduction to the Plymouth 'TROPHEE' workshop. J Exp Mar Biol Ecol 219:1-19

Buhr KJ (1976) Suspension-feeding and assimilation efficiency in Lanice conchilega (Polychaeta). Mar Biol 38:373-383

Clausen I, Riisgård HU (1996) Growth, filtration and respiration in the mussel Mytilus edulis: no regulation of the filterpump to nutritional needs. Mar Ecol Prog Ser 141:37-45

Clemmesen B, Jørgensen CB (1987) Energetic costs and efficiencies of ciliary filter-feeding. Mar Biol 94:445-449

Dales RP (1957) Some quantitative aspects of feeding in sabellid and serpulid fan worms. J Mar Biol Assoc UK 36: 309-316

Dales RP (1961) Observations on the respiration of the sabellid polychaete Schizobranchia insignis. Biol Bull 121:82-91

Davies BR, Stuart V, de Villiers M (1989) The filtration activity of a serpulid polychaete population (Ficopomatus enigmaticus (Fauvel)) and its effects on water quality in a coastal marina. Estuar Coast Shelf Sci 29:613-620

Dolmer P (2000a) Algal concentration profiles above mussel beds. J Sea Res 43:113-119

Dolmer P (2000b) Feeding activity of mussels Mytilus edulis as related to near-bed currents and phytoplankton biomass. J Sea Res 44:221-231

Fauchald K, Jumars PA (1979) The diet of worms: a study of polychaete feeding guilds. Oceanogr Mar Biol Annu Rev 17:193-284

Gallager SM (1988) Visual observations of particle manipulation during feeding in larvae of a bivalve mollusc. Bull Mar Sci 43:344-365

Gnaiger E (1983) Calculation of energetic and biochemical equivalents of respiratory oxygen consumption. In: Gnaiger E, Forstner H (eds) Polarographic oxygen sensors. SpringerVerlag, Berlin, p 337-345

Grémare A, Amouroux JM, Charles F, Dinet A, Riaux-Gobin C, Baudart J, Vétion G, Colomines JC (1997) Temporal changes in the biochemical composition and in the nutritional value of the particulate organic matter available to surface deposit-feeders: a two year study. Mar Ecol Prog Ser 150:195-206

Grémare A, Amouroux JM, Charles F, Nozais C, Baudart J, Medernach L, Jordana E, Vétion G, Colomines JC (1998a) Temporal changes in the biochemical composition of POM sedimenting in the coastal zone. A case study at a permanent site in the Bay of Banyuls-sur-Mer (Western Mediterranean). Oceanol Acta 21:783-792

Grémare A, Amouroux JM, Vétion G (1998b) Long-term comparison of macrobenthos within the soft bottoms of the Bay of Banyuls-sur-Mer (northwestern Mediterranean Sea). J Sea Res 40:281-302

Guille A (1971) Bionomie benthique du plateau continental de la côte catalane française. IV. Densités, biomasses et variations saisonnières de la macrofaune. Vie Milieu 22: 93-158

Hart M (1991) Particle captures and the method of suspension feeding by echinoderm larvae. Biol Bull 180:12-27

Hart M (1996) Variation in suspension feeding rates among larvae of some temperate, eastern Pacific echinoderms. Invertebr Biol 115:30-45

Hawkins AJS, Bayne BL (1992) Physiological interrelations, and the regulation of production. In: Gosling $\mathrm{E}$ (ed) The 
mussel Mytilus: ecology, physiology, genetics and culture. Elsevier, Amsterdam, p 171-222

Jacques G (1970) Aspects quantitatifs du phytoplancton de la région de Banyuls-sur-Mer (Golfe du Lion). Thèse Doctorat es Sciences Naturelles, Faculté des Sciences de Paris

Jordana E (2000) Cycle de vie, répartition géographique, production et nutrition d'une espèce actuellement en émergence dans le golfe du Lion: l'annélide polychète Ditrupa arietina. Thèse Doctorat Université Pierre et Marie Curie, Banyuls-sur Mer

Jordana E, Duchêne JC, Charles F, Grémare A, Amouroux JM (2000) Experimental study of suspension-feeding activity in the serpulid polychaete Ditrupa arietina (O.F. Müller). J Exp Mar Biol Ecol 252:57-74

Jørgensen CB (1975) Comparative physiology of suspension feeding. Annu Rev Physiol 37:57-79

Jørgensen CB (1990) Bivalve filter-feeding: hydrodynamics, bioenergetics, physiology and ecology. Olsen \& Olsen, Fredensborg

Jørgensen CB (1996) Bivalve filter-feeding revisited. Mar Ecol Prog Ser 142:287-302

Jørgensen CB, Kiørboe T, Møhlenberg F, Riisgård HU (1984) Ciliary and mucus net filter-feeding, with special reference to fluid mechanical characteristics. Mar Ecol Prog Ser 15:283-292

Kiørboe T, Møhlenberg F, Hamburger K (1985) Bioenergetics of the planktonic copepod Acartia tonsa: relation between feeding, egg production and respiration, and composition of specific dynamic action. Mar Ecol Prog Ser 26:85-97

Klöckner K (1978) Zur Ökologie von Pomatoceros triqueter (Serpulidae, Polychaeta). Helgol Wiss Meeresunters 31: 257-284

Lemmens JWTJ, Clapin G, Lavery P, Cary J (1996) Filtering capacity of seagrass meadows and other habitas of Cockburn Sound, Western Australia. Mar Ecol Prog Ser 143: $187-200$

Lindahl O (1988) Sedimentation and oxygen consumption below sill level in the Gullmar Fjord, Sweden. In: Wassmann P, Heiskanen AS (eds) Sediment trap studies in the Nordic countries 1; Workshop proceedings. Tvärminne Zoological Station, Finland, 24-28 February 1988

Lindahl O, Hernroth L (1988) Large-scale and long-term variations in the zooplankton community of the Gullmarfjord, Sweden, in relation to advective processes. Mar Ecol Prog Ser 43:161-171

Lisbjerg D, Petersen JK (2000) Clearance capacity of Electra bellula (Bryozoa) in seagrass meadows of Western Australia. J Exp Mar Biol Ecol 244:285-296

Mayer S (1994) Particle capture in the crown of the ciliary suspension feeding polychaete Sabella penicillus: videotape recordings and interpretations. Mar Biol 119:571-582

Mayer S (2000) Numerical simulation of flow fields and particle trajectories in ciliary suspension feeding. Bull Math Biol 62:1035-1059

Medernach L, Jordana E, Grémare A, Nozais C, Charles F, Amouroux JM (2000) Population dynamics, secondary production and calcification in a Mediterranean population of Ditrupa arietina (Annelida: Polychaeta). Mar Ecol Prog Ser 199:171-184

Menon NR (1974) Clearance rates of food suspension and food passage rates as a function of temperature in two North-Sea bryozoans. Mar Biol 24:65-67

Møhlenberg F, Riisgård HU (1979) Filtration rate, using a new indirect technique, in thirteen species of suspensionfeeding bivalves. Mar Biol 54:143-148

Nielsen C (1987) Structure and function of metazoan ciliary bands and their phylogenetic significance. Acta Zool (Stockh) 68:202-262

Nilsson HC, Rosenberg R (2000) Succession in marine benthic habitats and fauna in response to oxygen deficiency: analysed by sediment profile imaging and by grab samples. Mar Ecol Prog Ser 197:139-149

Petersen JK, Riisgård HU (1992) Filtration capacity of the ascidian Ciona intestinalis (L.) and its grazing impact in a shallow fjord. Mar Ecol Prog Ser 88:9-17

Petersen JK, Mayer S, Knudsen MÅ (1999) Beat frequency of cilia in the branchial basket of the ascidian Ciona intestinalis in relation to temperature and algal concentration. Mar Biol 133:185-192

Riisgård HU (1988a) The ascidian pump: properties and energy cost. Mar Ecol Prog Ser 47:129-134

Riisgård HU (1988b) Efficiency of particle retention and filtration rate in 6 species of Northeast American bivalves. Mar Ecol Prog Ser 45:217-223

Riisgård HU (1988c) Feeding rates in hard clam (Mercenaria mercenaria) veliger larvae as a function of algal (Isochrysis galbana) concentration. J Shellfish Res 7:377-380

Riisgård HU (2001) Physiological regulation versus autonomous filtration in filter-feeding bivalves: starting points for progress. Ophelia 54:193-209

Riisgård HU, Goldson A (1997) Minimal scaling of the lophophore filter-pump in ectoprocts (Bryozoa) excludes physiological regulation of filtration rate to nutritional needs. Test of hypothesis. Mar Ecol Prog Ser 156:109-120

Riisgård HU, Ivarsson NM (1990) The crown-filament-pump of the suspension-feeding polychaete Sabella penicillus: filtration, effects of temperature, energy cost, and modelling. Mar Ecol Prog Ser 62:249-257

Riisgård HU, Kamermans P (2001) Switching between deposit and suspension feeding in coastal zoobenthos. Ecol Stud 151:73-101

Riisgård HU, Larsen PS (1995) Filter-feeding in marine macroinvertebrates: pump characteristics, modelling and energy cost. Biol Rev 70:67-106

Riisgård HU, Larsen PS (2000) Comparative ecophysiology of active zoobenthic filter-feeding, essence of current knowledge. J Sea Res 44:169-193

Riisgård HU, Manríquez P (1997) Filter-feeding in fifteen marine ectoprocts (Bryozoa): particle capture and water pumping. Mar Ecol Prog Ser 154:223-239

Riisgård HU, Randløv A (1981) Energy budgets, growth and filtration rates in Mytilus edulis at different algal concentrations. Mar Biol 61:227-234

Riisgård HU, Svane I (1999) Filter feeding in lancelets (amphioxus) Branchiostoma lanceolatum. Invertebr Biol 118:423-432

Riisgård HU, Randløv A, Kristensen PS (1980) Rates of water processing oxygen consumption and efficiency of particle retention in veligers and young post-metamorphic Mytilus edulis. Ophelia 19:37-47

Riisgård HU, Randløv A, Hamburger K (1981) Oxygen consumption and clearance as a function of size in Mytilus edulis L. veliger larvae. Ophelia 20:179-183

Riisgård HU, Nielsen C, Larsen PS (2000) Downstream collecting in ciliary suspension feeders: the catch-up principle. Mar Ecol Prog Ser 207:33-51

Sand-Jensen K, Nielsen SL, Borum J, Geertz-Hansen O (1994) Fytoplankton- og makrofytudviklingen i danske kystområder ('Phytoplankton and macrophyte development in Danish coastal waters'). Havforskning fra Miljøstyrelsen 30:1-43 (Report published by the Ministry of the Environment; in Danish with English summary)

Shumway SE, Bogdanowicz C, Dean D (1988) Oxygen con- 
sumption and feeding rates of the sabellid polychaete Myxicola infundibulum (Renier). Comp Biochem Physiol A 90:425-428

Smaal A, Widdows J (1994) The scope for growth of bivalves as an integrated response parameter in biological monitoring. In: Kramer KJM (ed) Biomonitoring of coastal waters and estuaries. CRC Press Inc, Boca Raton, FL, p 247-267 Vedel A (1998) Phytoplankton depletion in the benthic

Editorial responsibility: Otto Kinne (Editor), Oldendorf/Luhe, Germany boundary layer caused by suspension-feeding Nereis diversicolor (Polychaeta): grazing impact and effect of temperature. Mar Ecol Prog Ser 163:125-132

Vedel A, Andersen BB, Riisgård HU (1994) Field investigations of pumping activity of the facultatively filter-feeding polychaete Nereis diversicolor using an improved infrared phototransducer system. Mar Ecol Prog Ser 103: 91-101

Submitted: May 3, 2001; Accepted: August 14, 2001 Proofs received from author(s): March 5, 2002 